УдК 343.985:343.123.12

\author{
О. О. Подобний
}

\title{
ЗАБЕЗПЕЧЕННЯ ПРАКТИЧНОЇ РЕАЛІЗАЦІї \\ ВИКОРИСТАННЯ КОНФІДЕНЦІЙНОГО СПІВРОБІТНИЦТВА ЯК НЕГЛАСНОї СЛІДЧОї (РОЗШУКОВОї) ДІї
}

Постановка проблеми. Актуальність окресленого предмета обумовлена тим, що за умов складної криміногенної ситуації сьогодення розслідування злочинів, передусім тих, що вчиняються організованими злочинними угрупованнями, обов'язково повинно здійснюватися шляхом комплексного застосування сил, засобів і методів оперативно-розшукової та кримінально-процесуальної діяльності. Однак указані правоохоронні функції нині знаходяться в активній фазі реформування їхніх правових та організаційних основ, що обумовлює необхідність подальшого докладного наукового осмислення механізму оперативно-розшукового забезпечення кримінального провадження, зокрема щодо практичної реалізації використання конфіденційного співробітництва як негласної слідчої (розшукової) дії (далі - НС(Р)Д).

Аналіз останніх досліджень і публікацій. У юридичній літератуpi проблематиці взаємодії слідчого з працівниками оперативних підрозділів приділялася значна увага. 3 позиції кримінального процесу та криміналістики ця проблема досліджувалася В.Д. Берназом, Р.С. Бєлкіним, Г.Ю. Бондарем, А.Ф. Волобуєвим, Л.Я. Гордіним, А.В. Дуловим, В.П. Лавровим, І.В. Лєшуковою, І.М. Лузгіним, М.А. Погорецьким, O.В. Старченком та іншими вченими [1-6]. Питанням взаємодії оперативних підрозділів зі слідчими в боротьбі зі злочинністю також приділялася значна увага в теорії оперативно-розшукової діяльності (далі - ОРД), зокрема В.М. Атмажитовим, О.М. Бандуркою, М.П. Водьком, Д.В. Гребельським, В.Л. Грохольським, О.Ф. Долженковим, К.К. Єрмаковим, І.О. Клімовим, І.П. Козаченком, М.В. Корнієнком, А.Г. Маркушиним та іншими авторами [7-9]. Спільна діяльність оперативних і слідчих підрозділів у боротьбі з організованою злочинністю в сучасних умовах реформування кримінального судочинства з позицій теорії оперативно-розшукової діяльності знайшла своє висвітлення в останніх наукових дослідженнях [10-12]. 
Метою статті є визначення шляхів практичної реалізації використання конфіденційного співробітництва як негласної слідчої (розшукової) дії в рамках оперативно-розшукового забезпечення кримінального провадження.

Виклад основного матеріалу. Питання оперативно-розшукового забезпечення діяльності слідчого в спеціальній літературі почало розглядатися досить давно $[13$, с. $13 ; 14$, с. 20]. Загалом сприймаючи ці підходи, вважаємо за необхідне уточнити низку суттєвих моментів з урахуванням останніх законодавчих новел.

Історично ОРД була одним із засобів кримінально-процесуального пізнання, призначена в тому числі для розширення можливостей останнього [15, с. 269-270]. 3 прийняттям Кримінального процесуального кодексу України в 2012 р. (далі - КПК України) [16] оперативно-розшукова діяльність фактично ввійшла до складу кримінально-процесуальної в провадженнях, за якими розпочато досудове розслідування. Це не нівелювало значення оперативно-розшукового забезпечення кримінального судочинства, а навпаки, піднесло його на якісно новий рівень, оскільки самостійно ані слідчий, ані прокурор не можуть кваліфіковано провести жодної з передбачених КПК України НС(Р)Д.

Відповідно до ст. 2 КПК України ОРд і кримінальна процесуальна діяльність на сьогодні покликані разом реалізовувати законодавчу вимогу щодо забезпечення швидкого повного та неупередженого розслідування й судового розгляду, а необхідність підвищення ролі й відповідальності кожної служби правоохоронних відомств у розслідуванні злочинів, комплексного використання із цією метою всіх сил і засобів підкреслюється в низці підзаконних нормативно-правових актів [17; 18].

Хоча у відомчій нормотворчості й досі активно застосовується термін «оперативно-розшукове супроводження слідства», у юридичній літературі обгрунтовано необхідність оперування терміном «оперативно-розшукове забезпечення». Це поняття визначено як систему заходів, переважно негласного характеру, кваліфіковано здійснюваних оперативними підрозділами під керівництвом слідчого та прокурора на стадіях досудового слідства й судового розгляду з метою створення оптимальних умов повного й об'єктивного процесу розслідування, припинення або нейтралізації протидіï учасників організованого злочинного угруповання виконанню правоохоронної функції держави та правосуддя, забезпечення безпеки учасників кримінального судочинства [10; 11].

У свою чергу створення оптимальних умов процесу розслідування розуміємо як один із напрямів оперативно-розшукового забезпечення кримінального провадження, що містить у собі такі елементи: оперативно-розшукове документування ще до початку кримінального провадження; проведення за дорученням слідчого чи прокурора комплексу НС(Р)Д, спрямованих на встановлення осіб, якими вчинено злочин, інших причетних до нього осіб, визначення місцезнаходження підозрюваного або осіб, які стали його жертвою, розшук викрадених предметів, цінностей, знарядь і засобів учинення злочину, встановлення слідів злочину; інформаційну 
підтримку прийняття таких відповідальних процесуальних рішень, як повідомлення про підозру й визначення підозрюваним запобіжних заходів, а також практична реалізація використання конфіденційного співробітництва як НС(Р)Д, передбаченої ст. 275 КПК України. Створення оптимальних умов процесу розслідування багатоепізодних, складних чи пов'язаних з організованою злочинною діяльністю кримінальних проваджень можливе лише під час застосування групового методу організації розслідування у формі слідчо-оперативної групи.

Таким чином, окремим напрямом створення оптимальних умов повного й об'єктивного процесу розслідування в межах оперативно-розшукового забезпечення проваджень про організовану злочинну діяльність є забезпечення практичної реалізації використання конфіденційного співробітництва як НС(Р)Д, передбаченої ст. 275 КПК України. Ця складна проблема на сучасному етапі розвитку оперативно-розшукового та кримінального процесуального законодавства, безумовно, потребує окремого грунтовного вивчення.

Відповідно до ч. 1 зазначеної статті слідчий має право використовувати інформацію, отриману внаслідок конфіденційного співробітництва з іншими особами, або залучати цих осіб до проведення негласних слідчих (розшукових) дій. Водночас п. 13 ст. 8 Закону України «Про оперативно-розшукову діяльність» передбачено, зокрема, право оперативних підрозділів мати негласних штатних і позаштатних працівників, тобто суб'єктами встановлення й безпосереднього здійснення цього заходу $є$ працівники оперативних підрозділів.

Досвід свідчить, що неможливо забезпечити розкриття злочинів і невідворотність відповідальності злочинців без протипоставлення їх кримінальній діяльності цілеспрямованого комплексу оперативно-розшукових заходів і слідчих дій, без використання як допоміжну інформацію даних, отриманих оперативно-розшуковим шляхом, без залучення громадян до співпраці в боротьбі зі злочинністю. Вікова практика використання негласних сил, засобів і методів поліцейськими та спеціальними службами різних країн у боротьбі з політичною й організованою злочинністю свідчить, що перше місце серед них, навіть за умов результативності сучасної електронної розвідки, справедливо займає агентурний метод. Агентурний метод $€$ формою реалізації, по-перше, права органів, що здійснюють оперативно-розшукову діяльність, на залучення окремих осіб на конфіденційній основі до підготовки та проведення оперативно-розшукових заходів; по-друге, можливості громадян використати право на захист своїх прав i законних інтересів від злочинних посягань [12].

Використання конфіденційного співробітництва в кримінальному провадженні можливо також у двох формах: 1) використання інформації, отриманої під час такого співробітництва; 2) залучення осіб, які співпрацюють на засадах конфіденційності, до проведення таких НС(Р) Д, передбачених КПК України, як контрольована й оперативна закупка (ст. 271); виконання спеціального завдання з розкриття злочинної діяль- 
ності організованої групи чи злочинної організації (ст. 272); створення й використання спеціально утворених підприємств, установ організацій (ст. 273); обстеження публічно недоступних місць житла чи іншого володіння особи (ст. 267); негласне отримання зразків, необхідних для порівняльного дослідження (ст. 274).

Щодо використання в кримінальному провадженні інформації, отриманої в результаті конфіденційного співробітництва, то таке використання $€$ можливим на різних етапах: на етапі реалізації матеріалів оперативно-розшукової діяльності, протягом досудового слідства тощо. Однак використання конфіденційного співробітництва $€$ найбільш ефективним саме на початковому етапі розслідування у формі оперативного перекриття затриманих та осіб, до яких як запобіжний захід застосовано тримання під вартою. Психологічна ситуація їх ізоляції від співучасників і звичного соціального оточення, що викликає природну необхідність спілкування, дозволяє шляхом оперативного відпрацювання отримати важливі для слідства фактичні дані, які належать до предмета доказування. Переваги цієї форми оперативно-розшукового забезпечення розслідування злочинної діяльності організованих злочинних угруповань полягають у тому, що отримана інформація з дотриманням правил конспірації може бути одразу залучена до процесу доказування шляхом проведення відповідних слідчих (розшукових) та НС(Р)Д. У такий спосіб забезпечується дотримання принципів повноти й об'єктивності доказування. На жаль, можливості такої НС(Р) Д, як використання конфіденційного співробітництва, використовуються не повністю, оскільки на стадії судового розгляду оперативне перекриття здебільшого необгрунтовано припиняється, а розвідувально-пошукова робота на стадії судового провадження взагалі застосовується у виняткових випадках. Ця остання проблема поки залишається нормативно не врегульованою чинним кримінальним процесуальним законодавством.

Розглянуті в статті положення дозволяють зробити висновок про те, що практична реалізація використання конфіденційного співробітництва як негласної слідчої (розшукової) дії в кримінальному провадженні можлива лише в межах його оперативно-розшукового забезпечення, оскільки зазначений негласний захід кваліфіковано може здійснюватися лише силами оперативних підрозділів.

\section{Література}

1. Бондар Г.Ю. Правове забезпечення взаємодії слідчих правоохоронних відомств у кримінальному судочинстві України : дис. ... канд. юрид. наук : спец. 12.00 .09 «Кримінальний процес та криміналістика; судова експертиза; оперативно-розшукова діяльність» / Г.Ю. Бондар ; Харківський національний університет внутрішніх справ. - Х., 2004. - 230 с.

2. Волобуєв А.Ф. Взаємодія слідчого з оперативними підрозділами при розслідуванні економічних злочинів / А.Ф. Волобуєв / / Форум права. - 2006. - № 1. - С. 16-19. - [Електронний ресурс]. - Режим доступу : http:/ / nbuv.gov.ua/j-pdf/FP_index.htm_2006_1_4.pdf.

3. Гордін Л.Я. Кримінально-процесуальні проблеми створення та діяльності слідчо-оперативних груп : автореф. дис. ... канд. юрид. наук : спец. 12.00.09 «Кримінальний процес та криміналістика; судова експертиза; оперативно-розшукова діяльність» / Л.Я. Гордін ; Національна юридична академія України імені Ярослава Мудрого. - Х., 2008. - 23 с. 
4. Лєшукова І.В. Процесуальні особливості міжнародного співробітництва органів внутрішніх справ України при розслідуванні злочинів : дис. ... канд. юрид. наук : спец. 12.00.09 «Кримінальний процес та криміналістика; судова експертиза; оперативно-розшукова діяльність» / I.В. Лєшукова ; Харківський національний університет внутрішніх справ. - Х., 2004. - 217 с.

5. Погорецкий Н.А. Взаимодействие следователя и органа дознания в процессе расследования преступлений / Н.А. Погорецкий / / Весы Фемиды. - 2000. - № 3-4. - С. 205-212.

6. Старченко О.В. Місце та роль зовнішньої взаємодії у слідчій діяльності : дис. ... канд. юрид. наук : 12.00 .09 «Кримінальний процес та криміналістика; судова експертиза; оперативно-розшукова діяльність» / О.В. Старченко / Донецький юридичний ін-т Луганського держ. ун-ту внутрішніх справ. - Донецьк, 2006. - 220 с.

7. Водько Н.П. Организация комплексной борьбы с рецидивной преступностью (на материалах оперативных аппаратов милиции и исправительно-трудовых учреждений) / Н.П. Водько. К. : РИО МВД УССР, 1981. - 160 с.

8. Грохольський В.Л. Організаційно-правові засади управління спеціальними підрозділами МВС України по боротьбі з організованою злочинністю : [монографія] / В.Л. Грохольський ; за заг. редакцією О.М. Бандурки. - Х. : Вид-во Нац. ун-ту внутр. справ, 2003. - 312 с.

9. Ермаков K.K. Взаимодействие и координация в органах внутренних дел : [лекция] / К.К. Ермаков. - М. : Высшая школа МВД СССР, 1991. - 24 с.

10. Подобний O.О. Теоретичні, правові та організаційно-тактичні основи оперативно-розшукової діяльності органів внутрішніх справ у боротьбі з корисливо-насильницькою організованою злочинністю : дис. ... докт. юрид. наук : спец. 12.00.09 «Кримінальний процес та криміналістика; судова експертиза; оперативно-розшукова діяльність» / О.О. Подобний. - О., 2014. - 468 с.

11. Подобний О.О. Оперативно-розшукове забезпечення кримінального провадження про корисливо-насильницьку організовану злочинну діяльність / О.О. Подобний / / Форум права. - 2013. - № 4. - [Електронний ресурс]. - Режим доступу : http://nbuv.gov.ua/j-pdf/ FP_index.htm_2013_4_52.pdf.

12. Шахматов А.В. Агентурная работа в оперативно-розыскной деятельности (теоретико-правовое исследование российского опыта) : дисс. ... докт. юрид. наук : спец. 12.00 .09 «головный процесс, криминалистика; оперативно-розыскная деятельность» / А.В. Шахматов ; Санкт-Петербургский университет МВД Российской Федерации. - СПб., 2005. - 441 с.

13. Хомколов В.П. Организация управления оперативно-розыскной деятельностью: системный поход / В.П. Хомколов. - М. : Закон и право ; ЮНИТИ, 1999. - 191 с.

14. Рябков Е.М. Правовые, организационные и тактические вопросы оперативно-розыскного обеспечения предварительного следствия по преступлениям, совершенным группой лиц : дисс. ... канд. юрид. наук / Е.М. Рябков. - М., 1990. - 200 с.

15. Погорецький М.А. Функціональне призначення оперативно-розшукової діяльності у кримінальному процесі : [монографія] / М.А. Погорецький. - Х. : Арсіс ; ЛТД, 2007. - 576 с.

16. Кримінальний процесуальний кодекс України : Закон України від 13 квітня 2012 р. № 394-VIII (станом на 13 травня 2015 р.) [Електронний ресурс]. - Режим доступу : http:/ / zakon1.rada.gov.ua.

17. Про затвердження Інструкції з організації взаємодії органів досудового розслідування $з$ іншими органами та підрозділами внутрішніх справ у попередженні, виявленні та розслідуванні кримінальних правопорушень : Наказ МВС України від 14 серпня 2012 р. № 700 [Електронний peсурс]. - Режим доступу : http:/ / zakon5.rada.gov.ua/laws.

18. Про затвердження Інструкції про взаємодію правоохоронних органів у сфері боротьби 3 організованою злочинністю : Наказ МВС України, Служби безпеки України від 10 червня 2011 р. № 317/235 [Електронний ресурс]. - Режим доступу : http:// http://zakon2.rada.gov.ua/ laws/show/z0822-11. 


\section{Ано т а ц і я}

Подобний О. О. Забезпечення практичної реалізації використання конфіденційного співробітництва як негласної слідчої (розшукової) дії. - Стаття.

Використання конфіденційного співробітництва як негласна слідча (розшукова) дія обгрунтовано складовою такого напряму оперативно-розшукового забезпечення кримінального провадження, як створення оптимальних умов процесу розслідування. Визначено форми використання конфіденційного співробітництва й негласні слідчі (розшукові) діiі, до проведення яких може залучатися особа, яка співпрацює на засадах конфіденційності.

Ключові слова: оперативно-розшукове забезпечення, кримінальне провадження, конфіденційне співробітництво.

\section{Анн о т а ци я}

Подобный $A$. $A$. Обеспечение практической реализации использования конфиденциального сотрудничества как негласного следственного (розыскного) действия. Статья.

Использование конфиденциального сотрудничества как негласного следственного (розыскного) действия обосновано составляющей такого направления оперативно-розыскного обеспечения уголовного производства, как создание оптимальных условий процесса расследования. Определены формы использования конфиденциального сотрудничества и негласные следственные (розыскные) действия, к проведению которых может привлекаться лицо, сотрудничающее на основе конфиденциальности.

Ключевые слова: оперативно-розыскное обеспечение, уголовное производство, конфиденциальное сотрудничество.

\section{S u m m a r y}

Podobniy A. A. Provision of the use of confidential cooperation as a covert investigative activity. - Article.

The use of a confidential cooperation as a covert investigative activity is justified by the creation of optimal conditions for the process of the investigation. The forms of the use of confidential and secret investigative cooperation (investigative) activity which may involve a person cooperating on the basis of confidentiality, were determined.

Key words: operational investigative support, criminal proceedings confidential cooperation. 